\title{
BİREYSEL EMEKLİLİK FONLARINI BELIIRLEYEN FAKTÖRLER: OECD ÖRNEĞİ
}

\author{
Sibel SELIM* \\ Orkun ÇELIK ${ }^{* *}$
}

\section{Özet}

Bu çalışmanın amacı, 2005-2011 yılları arasında 32 OECD ülkesi için panel veri regresyon modeli kullanılarak bireysel emeklilik fonlarını belirleyen faktörleri incelemektir. Bireysel emeklilik fonlarını belirleyen faktörler olarak, hane halkı tüketim harcamaları, toplam nüfus, kişi başına gayri safi yurtiçi hâsıla, kişi başına sağlık harcamaları, istihdam oranı, enflasyon, erkeklerin ortalama emeklilik yaşı, kısa dönem faiz oranı ve 2008 yılı krizini ifade eden kukla değişken ele alınmıştır. Panel veri analiz sonuçlarına göre bu çalışmada elde edilen sabit etkiler modelinde, farklı varyans ve otokorelasyon söz konusu olduğu için varsayımlara karşı dirençli tahminciler veren esnek genelleştirilmiş en küçük kareler regresyonu elde edilmiştir. Bu çalışmadan elde edilen bulgulara göre, hane halkı tüketim harcamaları, kişi başına gayri safi yurtiçi hâsıla, erkeklerin ortalama emeklilik yaşı değişkenleri bireysel emeklilik fonlarını negatif ve anlamlı bir şekilde etkilerken; nüfus, sağlık harcamaları ve istihdamın pozitif etkilemiştir. Enflasyon ve kısa dönem faiz oranının emeklilik fonları üzerindeki etkisi anlamsız bulunmuştur.

Anahtar Kelimeler: Bireysel emeklilik fonları, OECD ülkeleri, Panel veri analizi

Jel Kodları: C23, E20, E21

* Doç. Dr. , Celal Bayar Üniversitesi, İktisadi ve İdari Bilimler Fakültesi, Ekonometri Bölümü, sibel.selim@cbu.edu.tr.

Arş. Gör. , Ege Üniversitesi, İktisadi ve İdari Bilimler Fakültesi, İktisat Bölümü, orkun.celik@ege.edu.tr. (Sorumlu yazar) 


\title{
THE DETERMINANTS OF INDIVIDUAL PENSION FUNDS: THE CASE OF OECD
}

\begin{abstract}
The aim of this study is to examine the determinants of individual pension funds for 32 OECD countries using panel data regression model in 2005-2011. Household consumption expenditure, total population, gross domestic product per capita, health spending per capita, employment rates, inflation, men's average retirement age, short-term interest rate and the dummy variable expressing the 2008 crisis are taken as determinants of the individual pension funds. In this study, feasible generalized least squares regression estimators being resistant to these assumptions for heteroscedasticity and autocorrelation in the fixed effects models is obtained. According to the findings obtained from this study, while household consumption expenditure, gross domestic product per capita and the average retirement age of men affect negative and significantly pension funds; population, health expenditures and employment impact has been positive. The effect on pension funds of the short-term interest rates and inflation has been found to be insignificant.
\end{abstract}

Key words: Individual pension funds, OECD countries, Panel data analysis Jel Codes: C23, E20, E21

\section{GiRis}

Gelişmiş ve gelişmekte olan ülkelerin bir çoğunda sosyal devlet anlayışı yerine liberal politikaların yerleşmeye başlaması, ekonominin genelini etkilediği gibi bireylerin emeklilik kararlarını da etkilemektedir. Devletin ekonomideki faaliyet alanlarının daraltılması, bununla birlikte özel firmaların daha fazla faaliyet göstermesi sosyal güvenlik alanında bir takım değişimlerin yaşanmasını da beraberinde getirmiştir. Gelişmiş ülkelerde daha fazla eskiye dayanan ve gelişmekte olan ülkelerde de yeni yeni hakimiyet kurmaya çalışan bireysel emeklilik anlayışının özü, devlet elindeki bu fonların özel sektöre aktarlarak devletin ekonomideki rolünün daraltılması olmuştur. Bireysel anlamda bir yatırım veya geleceği garantileme anlayışı olarak görülse de, toplumsal anlamda aslında ekonomide bir fon birikimi sağlanarak tassarrufların artmasına yardımcı olmaktadır.

Finansal piyasalarda değerlendirilen emeklilik fonları ekonomiye uzun vadede kaynak yaratarak ekonomik kalkınmaya katkı yaratabileceği gibi, sermaye piyasasında kaynak aktararak piyasaların gelişmesi ve derinleşmesine katkıda sunabilmektedir. Ayrıca kamu ve özel sektörün borçlanma olanaklarını da kolaylaştırabilmektedir. Bu anlamda, bireysel emeklilik sisteminin ekonomik sistem ve finansal piyasalar içinde önemli bir misyon üstenlediği söylenebilir (Uyar, 2012: 73). Nitekim bireysel 
emeklilik sistemi düzenlenirken sosyal güvenlik fonksiyonu ile birlikte ülkenin ihtiyacı olan uzun vadeli yatrımlar için de gerekli olan fonların yatırılması, kamuya uzun vadeli borç imkanının sağlanması ve toplam yurtiçi tasarrufların arttırılması gibi amaçlar da dikkate alınmaktadır (Yılmaz ve Yaraşır, 2009: 113). Ayrıca bireysel emeklilik fonlarının ortaya çıkış amacı, doğrudan finans piyasalarıyla ilişkili olmayıp, 1980'li yıllarda çoğu ülkede ortaya çıkan sosyal güvenlik krizlerine yönelik alternatif çözüm önerilerinin bir sonucu olarak uygulanmaya başlanmıştır (Oktayer ve Oktayer, 2007: 57-58).

Bireysel emeklilik fonlarının gerek ferdi gerekse toplumsal olarak böyle bir öneme sahip olması, bu fonların belirleyicilerinin ortaya koyulmasını gerektirmektedir. Konuyla ilgili yapılan çalışmalara bakıldığında, daha çok emeklilik fonlarının birer portföy yatırım argümanı olarak değerlendirilip getiri analizleri üzerinde durulmuştur. $\mathrm{Bu}$ da aslında bireysel emeklilik fonlarının, birer tassarruf aracı olarak görülmesinden ziyade daha çok kısa vadeli yatırım aracı olarak değerlendirildiğini göstermektedir. Literatürdeki bu açığı gidermek amacıyla, 2005-2011 yılları arasında 32 OECD ülkesini kapsayan bu çalışmada, emeklilik fonlarının belirleyicileri araştııılmıştır.

Çalışmanın izleyen bölümleri şu şekildedir. İkinci bölümde konuyla ilgili yapılmış çalışmalara yer verilmiştir. Üçüncü bölümde, bireysel emeklilik sisteminin kısa bir tanım ve tarihçesine yer verilerek OECD ülkeleri için sahip olduğu önem vurgulanmıştır. Dördüncü bölümde, veri seti ve uygulanan yöntem hakkında genel bilgi verilmişıltir. Beşinci bölüm çalışmada kullanılan veri seti ve tanımlayıcı istatistikler ile modellerden elde edilen bulgulara yer verildiği ekonometrik analiz kısmından oluşmaktadır. Altıncı bölüm ise sonuç bölümüdür.

\section{LITERATÜR ARAŞTIRMASI}

Bireysel emeklilik fonlarıla ilgili literatürde yapılmış çalışmalarda genel olarak emeklilik fonlarının getiri oranlarının karşılaştırılması ve etkinlik analizi yapılmıştır. Ülke ekonomisine yapmış olduğu etki ve belirleyicileri üzerine ampirik çalışmaların nadir olması göze çarpmaktadır. Elde edilen çalışmalardan bazıları ise şunlardır:

Blöndal ve Scarpetta (1998), OECD ülkelerindeki emeklilik kararının belirleyicilerini ortaya koymaya çalışmıştır. Çalışmada Esnek Genelleştirilmiş En Küçük Kareler (Feasible Generalized Least Squares) yönteminden yararlanılmıştır. Çalışmanın sonuçları, 1990'lı yılların 
ortalarında tüm OECD ülkelerindeki emeklilik sisteminde 55 yaşından sonra çalışmanın finansal olarak itici geldiğini göstermektedir. 1960’lı yıllardan beri, çoğu ülkedeki çalışanlar üzerindeki örtülü vergiler giderek artmıştır. Sürekli çalışmayı önlemek için alınan mali tedbirler, işsizlik ve malullük ile ilişkili erken emeklilik programlarıyla güçlendirilmiştir. Havuzlanmış zaman serisi regresyonları da, ileri yaşlarda çalışmak için alınan caydırıcı önlemlerin özellikle ileri yaştaki erkek çalışanların işgücü piyasasına katılımını azalttığını göstermektedir. Çalışma aynı zamanda bu durumun birçok ülkedeki emek piyasasının kötüleşmesinde de önemli bir rol oynadığını belirtmektedir.

Chan-Lau (2004)'da, gelişmekte olan piyasalardaki emeklilik fonları incelenmiştir. Yatırım performanslarının belirleyicileri olarak, yatırım düzenlemeleri, yatırım uygulamaları ve portföy alanlarını çeşitlendirmek ve geliştirmek için emeklilik fonu yöneticilerinin yetenekleri dikkate alınmıştır.

Bebczuk ve Musalem (2006) çalışmalarında, 1980-2004 yılları arasında 48 gelişmiş ve gelişmekte olan ülkeler için emeklik fon sistemlerinin ulusal tasarruf üzerindeki etkisi incelenmiştir. Yöntem olarak panel veri analizi yönteminden yararlanılmıştır. Elde edilen sonuçlara göre, emeklilik tasarruflarındaki bir dolarlık bir artış, ulusal tasarruf üzerindeki üzerinde ki etkisi 0-20 cent arasında bir artış yaratmaktadır. Zorunlu katılım ve portföy bileşiminin sonuçlar üzerinde bir etkisine ulaşılmayıp, sistemdeki vadenin ulusal tasarruflar üzerinde yüzde 0.3-0.5 arasında güçlü bir etki yaratmıştır. Reformcu ülkelerin diğerlerine göre daha fazla bir tasarruf yarattığ görülememiştir. GSYİH'deki büyüme oranı, enflasyon, dış ticaret hadlari ve cari açık ile pozitif ilişkiye sahip iken, yaşlıların bağımlılık oranı ve kentleşme oranının tasarruflarla olan ilişkisi negatif bir etkiye sahip olduğu sonucuna varılmıştır.

Bikker vd. (2009)'da, katılımcı yaş dağılımının Alman emeklilik fonlarının portföy dağılımı üzerindeki etkisi araştırılmıştır. Çalışmada 2007 y1lı için emeklilik fonu yatırım planları veri setinden yararlanılmıştır. Elde edilen modellerde En Küçük Kareler Yöntemi’nden faydalanılarak, emeklilik fonları üzerinde katılımcıların yaşının etkisi olduğu hesaplanmıştır. Bununla birlikte, emekli ya da pasif katılımcıların, aktif katılımcılara göre yatırım davranışları üzerinde ortalama yaşın etkisinin çok daha fazla olduğu belirtilmiştir. 
Şener ve Akın (2010), Türkiye'de bireysel emeklilik sistemine giriş kararlarını etkileyen faktörler belirlenmeye çalışılmıştır. Çalışma 400 deneği kapsayacak şekilde anket yöntemi kullanılarak hesaplanmıştır. Çalışmada, bireylerin \%70'inin reform çalışmalarının sosyal güvenlik alanındaki sorunları çözmeyeceği belirtilmiştir. Ayrıca gelir düzeyinin bireysel emeklilik sistemine giriş kararında önemli bir etken olduğu tespit edilmiştir. Bireylerin gelir düzeyi arttıkça sisteme girişi olumlu etkilemekte ve yatıracakları katkı paylarının artmasında da belirleyici bir rol üstlenmektedir. Diğer bir etken ise emeklilik düzeyidir. Eğitim düzeyi arttıkça, bireylerin sisteme dâhil olma konusunda daha istekli olduğu görülmüştür. Meslekler dikkate alındığında özellikle serbest gelir elde eden bireyler, ücretli çalışanlara göre sisteme daha dazla giriş yapmaktadır.

Njuguna (2011) Kenya'da emeklilik fonlarının yönetişim belirleyicilerini ortaya koymaya çalışmıştır. Çalışmada yöntemsel olarak Pearson korelâsyonları, regresyonlar, Scheffé testleri ve ANOVA test istatistiğinden yararlanılmıştır. Fonların belirleyicileri olarak, emeklilik düzenlemeleri, emeklilik plan tasarımı, üyelik yaşı, üye sayısı, plan liderliği ele alınmıştır. Ampirik bulgulara göre, emeklilik fonlarının yönetişimi, emeklilik düzenlemeleri, liderlik ve üyelik yaşından etkilenmektedir. Emeklilik plan tasarısı ve üye sayısının bir etkisi olmadığı gözlenmiştir.

Guillén (2011), sekiz Latin Amerika ülkesinde bireysel emeklilik fonlarının kırılganlıklarını ortaya koymaya çalışmıştır. Veri Zarflama Analizinden yararlanılarak elde edilen sonuçlar, Kotlikoff (2008)'in bireysel emeklilik fonlarının, riskli varlıkların piyasa dalgalanmalarıyla ilişkili olduğu sonuçlarını destekler niteliktedir. Ayrıca çalışmada portföylerin heterojen olmasının yönetim performansıyla ilişkili olmadığ 1 vurgulanmıştır. Yerel piyasa gücü, bireysel emeklilik fon kurumları için iyi bir portföy gücü yaratmada yeterli değildir. Politika yapıcılarının sistemde istikrarı ödün vermeden onları daha rekabetçi hale getirerek bireysel emeklilik fonları kurumları verimliliğini artırmak gerektiği sonuçlarına ulaşılmıştır.

Uyar (2012), Türkiye'de 2004-2009 yılları arasında bireysel emeklilik sisteminin makro ekonomik değişkenler üzerindeki etkisini incelenmiştir. Çalı̧̧mada yöntem olarak Riske Maruz Değer- VAR modellerinden yararlanılmıştır. Elde edilen bulgulara göre, bireysel 
emeklilik sistemindeki katılımcı sayısı, sertifika sayıs1 ve toplam yatırım tutarı ile İMKB endeksi, enflasyon (TÜFE), döviz kuru (dolar), büyüme oranı ve dış ticaret verileri (ihracat ve ithalat) arasında anlamlı bir ilişki tespit edilememiştir. Çalışmada sertifika sayısı ile mevduat faizi arasında anlamlı bir ilişkinin olduğu tespit edilmiştir. İlgili dönemden bir önceki dönemin mevduat faizi ilgili dönemin sertifika sayısını etkileşim içinde olduğu sonucuna ulaşılmıştır. Söz konusu dönemdeki sertifika sayısı ise bir sonraki dönemin mevduat faizini etkilemektedir.

López-Villavicencio ve Rigot (2013)'da, Amerika ve Kanada'da 1996-2011 yılları arasında özel sermaye fonlarındaki emeklilik fonu yatırımlarının temel belirleyicileri ortaya konulmaya çalışılmıştır. Çalı̧̧mada Tobit modelinden yararlanılmıştır. Elde edilen sonuçlar, özel sermayeye ayrılan emeklilik fonları ve daha geleneksel olan varlıkların arasında önemli farklılıklar olduğunu göstermiştir. Bu farklılıklardan biri de, özel sermayeye ayrılan emeklilik fonlarının daha büyük ve özel fonlar tarafından çeşitlendirilmesidir. Ayrıca bu tür fonlar üyelerin yaşlarıyla ilgilenmemekte ve daha yüksek bir getiri oranı sunmaktadır.

\section{OECD ÜLKELERINDE BİREYSEL EMEKLİLIKK SİSTEMI}

Emeklilik geliri, insan yaşamı boyunca son derece önemli gelirlerden biri olmuştur. Yaşlılık döneminde, bu gelirler dört şekilde görülmektedir. Bunlar; finanse edilmemiş devlet emekliliği (vergi sistemi yoluyla çalışan nüfustan transfer edilen), finanse edilmiş özel emeklilik (özel sektör emeklilik sisteminde biriktirilmiş tasarruflardan), doğrudan özel tasarruflar ve emeklilik sonrası çalışmalardan elde edilen gelirlerden oluşmaktadır (Blake, 2003: 1). Bu dört gelir türünden biri olan kişisel tasarrufların arkasındaki motivasyon ise, az yada çok yaşamın geneline eşit olarak yayılan tüketim olanağını sağlamasıdır. Tüketimin yaşam döngüsü hipotezine göre, hane halkları zaman içerisinde kişi başına düşen fayda düzeyini durağan bir durumda sürdürmeye çalışmaktadır. Genellikle bunu da, başlangıçta borçlanarak (ev satın almak için) ve sonra ödenmemiş kredileri ödemek amacıyla tasarruf yaparak ve gelirinin azalabileceği durumda emekliliğini göz önüne alarak yapmaktadır (Cordina ve Grech, 1999: 63).

Dünyanın birçok ülkesinde uzun yıllardan beri uygulanmakta olan bireysel emeklilik sistemi, var olan emeklilik sistemlerini tamamlayıcı bir niteliğe sahip olmaktadır. Bireysel emeklilik sistemi sayesinde hızlı bir gelişim gösteren emeklilik fonları sisteminin 
uygulandığ 1 ülkelerde, emeklilik fonları önemli bir ekonomik unsur haline gelmiştir (Korkmaz ve Uygurtürk, 2007: 38). Şekil 1'de 2012 yılında OECD ülkelerindeki emeklilik fonlarının, Gayri Safi Yurtiçi Hâsılaları içindeki payları gösterilmiştir. Buna göre, Hollanda, İzlanda ve İsviçre'deki emeklilik fonlarının GSYH oranının daha fazla olduğu görülmektedir. Ayrıca bu ülkelerle birlikte İngiltere, Avustralya ve Finlandiya' daki bu oran OCED ülke ortalamaları üzerinde yer almıştır.

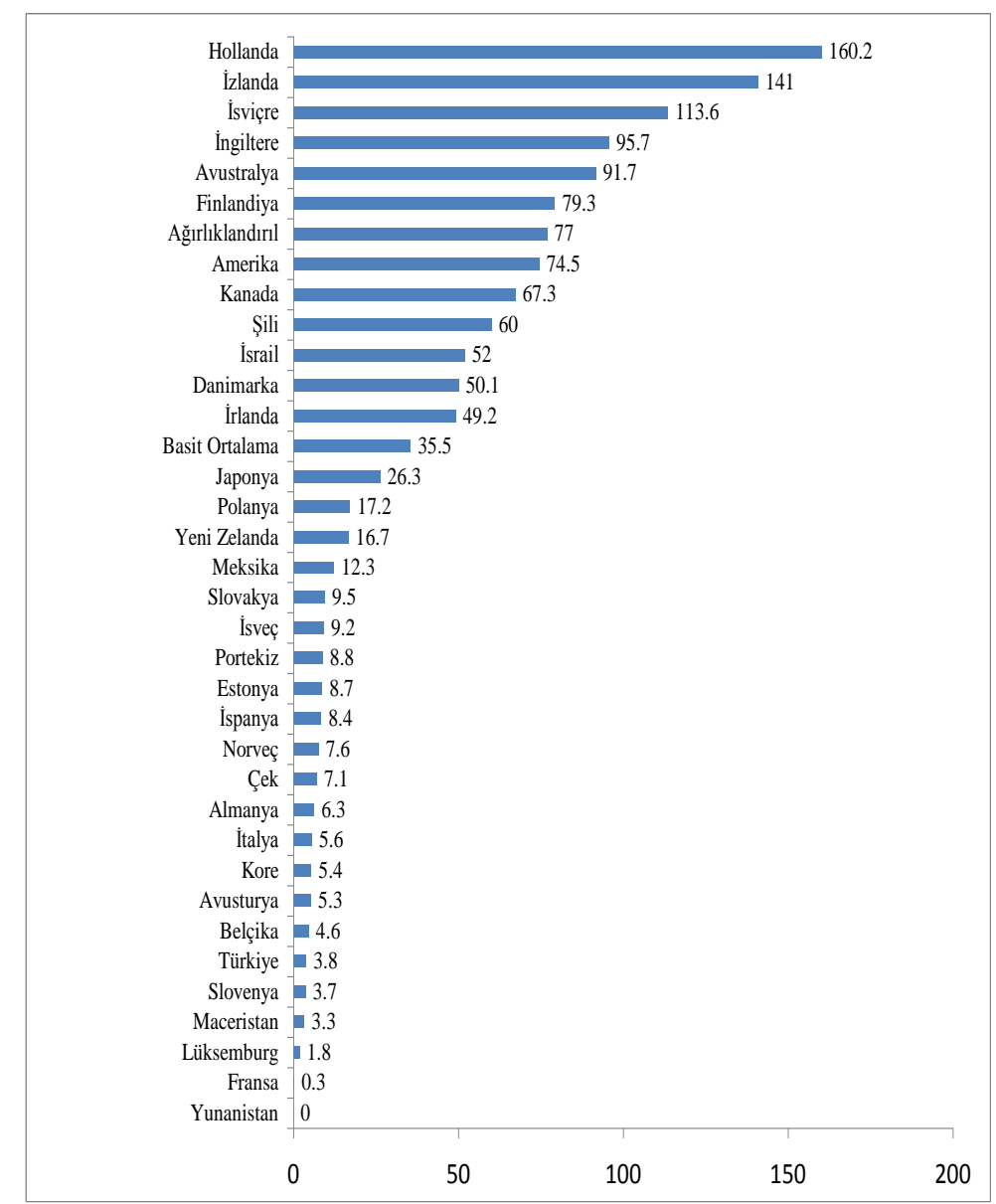

Kaynak: OECD, Pension Market in Focus 2013, s.11.

Şekil 1. OECD Ülkelerinde Emeklilik Fonlarının GSYİH İçerisindeki Payları (\%)

Tarihsel olarak bakıldığında, bireysel emeklilik fonlarının geçmişi 19. yüzyılın ortalarına kadar dayanmaktadır. İlk bireysel 
emeklilik fonu, 1862 yılinda Avustralya'da Bank of New South Wales tarafindan oluşturulmuştur (Karabay vd, 2012: 124). Daha sonra farklı şekillerde farklı ülkelerde uygulanır hale gelmiştir. 20. yüzyılın sonlarına doğru gelindiğinde ise, dünya genelinde yaşlanan nüfusun artmış olmasıyla birlikte tıp alanında yaşanan gelişmelere bağlı olarak beklenen yaşam süresinin uzamış olması aktif/pasif sigortalı dengesini bozmuş ve dağıtım esaslı işleyen sosyal güvenlik sistemi üzerinde önemli bir külfet oluşturmuştur. Bununla birlikte, dağıtım sisteminde yaşanan finansal sorunlara yönelik, fonlamaya dayalı bir sisteme doğru bir yönelimin olduğu, bu da uzun vadeli sigorta kollarından çok ayaklı emeklilik sistemlerine geçişle aşılmaya çalışılmıştır. Bu uygulamalardan ilki 1981 y1lında Şili'de başlamıştır. Reform niteliğindeki Şili örneği, daha sonraki yıllarda birçok ülke için örnek haline gelmiştir (Apak ve Taşcyyan, 2010: 121).

Ayrıca 2005-1011 yılları arasında OECD ülkelerinde emeklilik fon değerleri genel olarak değerlendirildiğinde Şekil 2'de görüldüğü gibi emeklilik fonlarında yaşanan 2008 krizi ile birlikte bir düşüş meydana gelmiş ve kriz sonrası tekrar yükselişe geçmiştir.

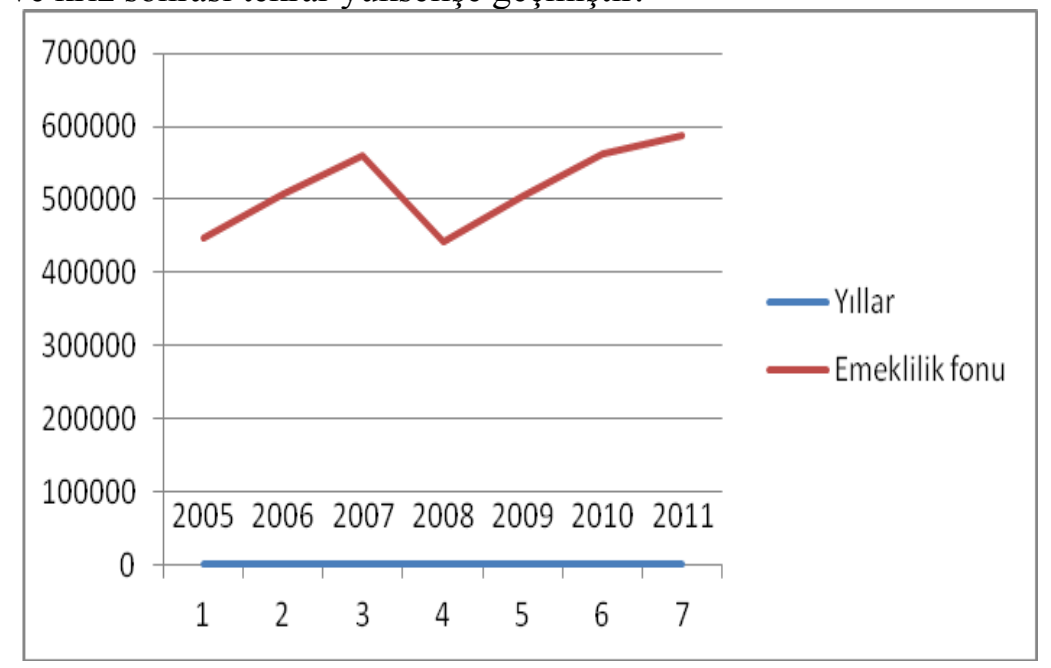

Kaynak: OECD veri tabanından alınan veriler tarafımızca düzenlenmiştir.

Şekil 2. OECD Ülkelerine Ait Emeklilik Fon Değeri (2005-2011)

Günümüzdeki emeklilik sistemleri, üç temel üzerine oturtulmuştur. Bunlar; 
I. Kamunun finanse ettiği ve emeklilik maaş miktarının tanımlı olduğu yaygın zorunlu emeklilik sistemi,

II. Özellikle son yıllarda gelişmekte olan ülkelerde yaygınlaşan zorunlu bireysel emeklilik sistemi,

III. Ülkemizde de uygulanan gönüllü bireysel emeklilik sisteminden oluşmaktadır (Özel ve Yalçın, 2013: 4).

Çalışmanın kapsamını oluşturan 32 OECD ülkesinin tamamı incelendiğinde, Tablo 1'de görüldüğü gibi ülkelerin dönem içerisinde emeklilik sistemlerinde reformlar yaptıkları görülmektedir. Belçika ve Şili gibi bazı ülkelerde reform, önceki 5 yıllık dönemde (2004-2008) kabul edilen mevzuat şartları altındaki önemlere uyumu gerektirmektedir. O zamandan beri, reformlar yaşlanan nüfus ve ekonomik krizin sonuçlarına çözümünde idari etkinliği ve finansal sürdürebilirliği geliştirmeye artan bir şekilde odaklanmaktadır. Yunanistan ve İrlanda gibi ülkelerde reformlar, ekonomik krizden en kötü etkilenen faydalarının hesaplanması yoluyla revize edilmiştir (OECD, 2013b: 20). 
Tablo 1. OECD Ülkelerindeki Emeklilik Reformları (2009-2013)

\begin{tabular}{|c|c|c|c|c|c|c|c|}
\hline Ülkeler & $\begin{array}{c}\text { Kapsa } \\
\text { m }\end{array}$ & $\begin{array}{l}\text { Uygunl } \\
\text { uk }\end{array}$ & $\begin{array}{c}\text { Sürdürebilir } \\
\text { lik }\end{array}$ & $\begin{array}{c}\text { Çalışma } \\
\text { Teşvikle } \\
\text { ri }\end{array}$ & $\begin{array}{c}\text { İdari } \\
\text { Etkinli } \\
\text { k }\end{array}$ & $\begin{array}{c}\text { Çeşitlendir } \\
\text { me/ } \\
\text { Güvenlik }\end{array}$ & $\underset{\mathbf{r}}{\text { Diğe }}$ \\
\hline Avustralya & $\mathrm{x}$ & $\mathrm{x}$ & $\mathrm{x}$ & $\mathrm{X}$ & $\mathrm{X}$ & & $\mathrm{x}$ \\
\hline Avusturya & $\mathrm{x}$ & $\mathrm{x}$ & $\mathrm{x}$ & & & & $\mathrm{x}$ \\
\hline Belçika & & & & $\mathrm{x}$ & & & \\
\hline Kanada & $\mathrm{x}$ & & $\mathrm{x}$ & $\mathrm{x}$ & & $\mathrm{x}$ & $\mathrm{x}$ \\
\hline Şili & $\mathrm{x}$ & $\mathrm{x}$ & & & $\mathrm{x}$ & $\mathrm{x}$ & $\mathrm{x}$ \\
\hline $\begin{array}{l}\text { Çek } \\
\text { Cumhuriy } \\
\text { eti }\end{array}$ & & & $\mathrm{x}$ & $\mathrm{x}$ & & $\mathrm{x}$ & \\
\hline $\begin{array}{l}\text { Danimark } \\
\text { a }\end{array}$ & & & & $\mathrm{x}$ & $\mathrm{x}$ & & \\
\hline Estonya & & $\mathrm{X}$ & $\mathrm{X}$ & $\mathrm{X}$ & $\mathrm{X}$ & $\mathrm{X}$ & \\
\hline Finlandiya & $\mathrm{x}$ & $\mathrm{x}$ & $\mathrm{x}$ & $\mathrm{x}$ & & $\mathrm{x}$ & \\
\hline Fransa & $\mathrm{x}$ & $\mathrm{x}$ & $\mathrm{x}$ & $\mathrm{x}$ & & & $\mathrm{x}$ \\
\hline Almanya & & $\mathrm{x}$ & $\mathrm{x}$ & $\mathrm{x}$ & & & \\
\hline $\begin{array}{l}\text { Yunanista } \\
\text { n }\end{array}$ & & $\mathrm{x}$ & $\mathrm{x}$ & $\mathrm{x}$ & $\mathrm{x}$ & & \\
\hline $\begin{array}{l}\text { Macarista } \\
\text { n }\end{array}$ & & $\mathrm{x}$ & $\mathrm{x}$ & $\mathrm{x}$ & & $\mathrm{x}$ & $\mathrm{x}$ \\
\hline İzlanda & & & & & & & $\mathrm{x}$ \\
\hline İrlanda & $\mathrm{x}$ & & $\mathrm{x}$ & $\mathrm{x}$ & & $\mathrm{x}$ & $\mathrm{x}$ \\
\hline İsrail & $\mathrm{x}$ & $\mathrm{X}$ & & & & $\mathrm{x}$ & \\
\hline İtalya & & $\mathrm{x}$ & $\mathrm{x}$ & $\mathrm{x}$ & $\mathrm{x}$ & & \\
\hline Japonya & $\mathrm{x}$ & $\mathrm{x}$ & $\mathrm{x}$ & & $\mathrm{x}$ & & $\mathrm{x}$ \\
\hline Kore & $\mathrm{x}$ & & $\mathrm{x}$ & & $\mathrm{x}$ & & \\
\hline $\begin{array}{l}\text { Lüksembu } \\
\text { rg }\end{array}$ & $\mathrm{x}$ & & $\mathrm{x}$ & $\mathrm{x}$ & & & \\
\hline Meksika & & $\mathrm{x}$ & & & $\mathrm{x}$ & $\mathrm{x}$ & \\
\hline Hollanda & & & & & & $\mathrm{x}$ & \\
\hline $\begin{array}{l}\text { Yeni } \\
\text { Zelanda }\end{array}$ & & $\mathrm{x}$ & $\mathrm{x}$ & & & & $\mathrm{x}$ \\
\hline Norveç & & $\mathrm{x}$ & $\mathrm{x}$ & $\mathrm{x}$ & & & \\
\hline Polanya & $\mathrm{x}$ & & $\mathrm{x}$ & $\mathrm{x}$ & & $\mathrm{x}$ & \\
\hline Portekiz & $\mathrm{x}$ & $\mathrm{x}$ & $\mathrm{x}$ & $\mathrm{x}$ & & $\mathrm{x}$ & \\
\hline Slovakya & & & $\mathrm{x}$ & & $\mathrm{x}$ & $\mathrm{x}$ & \\
\hline Slovenya & $\mathrm{x}$ & $\mathrm{x}$ & $\mathrm{x}$ & $\mathrm{x}$ & $\mathrm{x}$ & $\mathrm{x}$ & \\
\hline İspanya & & $\mathrm{x}$ & $\mathrm{x}$ & $\mathrm{x}$ & & & \\
\hline İsveç & & $\mathrm{x}$ & $\mathrm{x}$ & $\mathrm{x}$ & $\mathrm{x}$ & $\mathrm{x}$ & \\
\hline İsviçre & & & $\mathrm{x}$ & & & $\mathrm{x}$ & \\
\hline Türkiye & & & & $\mathrm{x}$ & & $\mathrm{x}$ & $\mathrm{x}$ \\
\hline İngiltere & $\mathrm{x}$ & $\mathrm{x}$ & $\mathrm{x}$ & $\mathrm{x}$ & $\mathrm{x}$ & $\mathrm{x}$ & $\mathrm{x}$ \\
\hline $\begin{array}{l}\text { Amerika } \\
\text { Birleşik } \\
\text { Devletleri }\end{array}$ & $\mathrm{x}$ & $\mathrm{x}$ & $\mathrm{x}$ & & & & \\
\hline
\end{tabular}

Kaynak: OECD, 2013b: 20.

\section{METODOLOJI}

Baltagi (2008)'ye göre, panel veri, ülkeler, firmalar, hanehalkları, vb. kesit gözlemlerinin belli bir zaman dönemi içinde bir araya getirilmesi durumudur. Panel veri ile, zaman serileri ve kesit 
serileri birleştirilerek, hem zaman hem de kesit boyutuna sahip veri seti oluşturulmaktadır (Hsiao, 1985). Oluşturulan bu panel veri seti, geniş̧ yatay kesit verilerinin dar bir zaman dilimi için gözlenebilmesi durumunda kısa panel, öte yandan az sayıdaki yatay kesit verilerinin geniş zaman dilimi için gözlenebilmesi durumunda ise, uzun panel olarak adlandırılmaktadır (Bilginoğlu ve Maraş, 2011: 63). Panel veri analizinin yaygınca kullanılmasının nedeni bir takım avantajlara sahip olmasından kaynaklanmaktadır.

Panel veri analizi yönteminin avantajlarından ilki, kişilerin, firmaların, ülkelerin, vs., zaman içinde ilişki kurulması nedeniyle bu birimlerin aralarında heterojen olması kaçınılmaz olması gösterilmektedir. İkincisi, yatay kesit gözlemlerin zaman serisiyle birleştirilerek daha bilgilendirici veriler, daha fazla değişkenlik ve değişkenler arasında daha az doğrusallık, daha fazla serbestlik derecesi ve daha etkin bir model sağlamaktadır. Üçüncüsü, tekrar eden yatay kesit gözlemleriyle çalışıldığından, panel veri "değişim dinamiklerini" çalışmak için daha uygun bir yöntem olmaktadır. Dördüncüsü, sadece yatay kesit ya da sadece zaman serisinde gözlenemeyen etkileri daha iyi teşhis edilmekte ve ölçülmektedir. Son olarak, daha karmaşık davranışlara sahip modeller üzerinde çalışma imkânı sağlaması gösterilmektedir (Güvenek ve Alptekin, 2010: 179-180).

Panel veri regresyon modelini aşağıdaki gibi ifade edilebilmektedir

(Baltagi, 2008: 13; Erkan, 1999: 81);

$y_{i t}=\alpha_{i t}+X_{i t}^{\prime} \beta_{k}+u_{i t} i=1, \ldots \ldots \ldots, \quad t=1 \ldots \ldots \ldots T$

Burada $\alpha$, skaler, $\beta, \mathrm{Kx} 1$ boyutunda parametre ve $X_{i t}, k$, açıklayıcı değişken üzerinde $i$. gözlemin değeridir. Böyle bir modelde, hata teriminin sıfır ortalama ve $\sigma_{\varepsilon}^{2}$ varyansla normal dağıldığı kabul edilmektedir. Ayrıca her bir yatay kesit birim için gözlemler korelasyonsuz, birim ve zamana karşı hatalar eşit varyanslı olmaktadır (Johnston ve Dinardo, 1997: 390; Özer ve Biçerli, 2003). Panel veri modellerini sabit etkiler modeli ve tesadüfi etkiler modeli şeklinde incelemek de söz konusudur (Greene, 2003). Sabit etkiler modelinde yatay kesit birimleri arasındaki farklar sabit terimdeki farkl1lıklarla 
açıklanmakta ve panel veri modeli kukla değişken yardımıyla tahmin edilmektedir. Ayrıca bu modelde çok sayıda kukla değişkenin kullanılması sebebiyle serbestlik derecesi düşmekte ve çoklu doğrusal bağıntı problemi ortaya çıkmaktadır (Kennedy, 2006: 332). Eşitlik (2)'de sabit etkiler modelinde $\beta_{2 \text { it }}=\beta_{2}, \quad \beta_{3 i t}=\beta_{3}$ olduğu varsayılmaktadır. Böylece eşitlik;

$Y_{i t}=\beta_{1 i}+\beta_{2} X_{2 i t}+\beta_{3} X_{3 i t}+\ldots+\beta_{k i t} X_{K i t}+u_{i t}$

şeklinde yazılabilmektedir. $\beta_{1}$, ifadesindeki $i$ harfi kesiti simgelemekte ve sabitin kesitlere göre değiştiğini göstermektedir (Gujarati, 2004; Çetin ve Ecevit, 2010, Selim vd., 2014).

Rassal etkiler modelinde ise, yatay kesit birimlerinde veya birimlere ve zamana göre meydana gelen değişiklikler, modele hata teriminin bir bileşeni olarak dâhil edilmektedir (Baltagi, 2008). Rassal etkiler modelinde $i$, kesitleri ve $t$ zamanı göstermek üzere aşağıdaki model tahmin edilmektedir.

$Y_{i t}=\alpha+X_{i t}^{\prime} \beta+\left(\mu_{i}+v_{i t}\right) \quad i=1, \ldots, \mathrm{N} \quad t=1, \ldots, \mathrm{T}$

Modelde $X_{i t}$, açıklayıcı değişkenler vektörünü; $Y_{i t}$, bağımlı değişkeni; $\beta$, değişken katsayılarını ve $\alpha$, sabit terimi göstermektedir. Burada hata terimlerinin, varyanslarının sıfıra eşit olacak şekilde bağımsız ve özdeş dağıldığı kabul edilmektedir. $\mu_{i}$, birimlerde meydana gelen gözlenemeyen rassal farkları içeren hata terimi iken, $v_{i t}$ geri kalan hataları içeren terimdir (Bayraktutan ve Demirtaş, 2011; Selim vd., 2014).

Panel veri analiz modelinde hata terimine ait varsayımların gerçekleşmediği durumda bu varsayımlara karşı dirençli tahminciler veren FGLS yöntemi kullanılmıştır. Genelleştirilmiş en küçük kareler yöntemi, varyans kovaryans matrisinin bilindiği durumlarda kullanılabilmektedir. Ancak çoğu durumda varyans kovaryans matrisi bilinmemektedir ve tahmin edilmesi gerekmektedir. Bu durumda FGLS Yöntemi kullanılmaktadır (Tatoğlu, 2012:102). 


\section{EKONOMETRIKK ANALIZ}

\subsection{Veri Seti ve Tanımlayıcı İstatistikler}

$\mathrm{Bu}$ çalışmada, Yunanistan ve Japonya'ya ait emeklilik fon verilerine ulaşılamaması nedeniyle bu iki ülke çalışma kapsamı dışında tutularak Tablo 2'de belirtilen 32 OECD ülkesi için veriler kullanılarak analizler yapılmıştır. 32 OECD ülkesi için 2005-2011 y1lına ait veriler, OECD veri bankası ve Dünya Bankası, Dünya Kalkınma Göstergeleri (World Development Indicators)'nden elde edilmiştir.

Tablo 2. 32 OECD Ülkesine Ait Emeklilik Fon Değeri Verileri (Milyon \$)

\begin{tabular}{|c|c|c|c|c|c|c|c|}
\hline & \multicolumn{7}{|c|}{ Yillar } \\
\hline Ülkeler & 2005 & 2006 & 2007 & 2008 & 2009 & 2010 & 2011 \\
\hline Avustralya & 550340.3 & 649928.8 & 978246.4 & $\begin{array}{r}1056795 . \\
3\end{array}$ & 844481.1 & 990640.0 & 1400928.1 \\
\hline Avusturya & 13833.2 & 16783.0 & 19358.6 & 17460.1 & 20259.3 & 20332.8 & 19103.2 \\
\hline Belçika & 15708.5 & 17601.4 & 21774.7 & 15874.5 & 19878.8 & 17782.8 & 20224.8 \\
\hline Kanada & 686688.8 & 786329.3 & 966116.3 & 673332.9 & 879373.2 & 1047503.6 & 1072055.6 \\
\hline Şili & 74507.8 & 88293.5 & 111276.6 & 74312.7 & 118052.5 & 148437.0 & 134962.3 \\
\hline $\begin{array}{l}\text { Çek } \\
\text { Cumhuriye } \\
\text { ti }\end{array}$ & 5019.4 & 6991.2 & 9248.6 & 9909.3 & 11752.5 & 12395.2 & 12412.7 \\
\hline Danimarka & 82517.9 & 94024.8 & 108166.7 & 155961.3 & 138350.8 & 154612.1 & 154535.3 \\
\hline Estonya & 351.0 & 632.0 & 1043.1 & 1023.4 & 1371.7 & 1430.7 & 1467.3 \\
\hline Finlandiya & 127349.8 & 156919.2 & 186956.7 & 156896.1 & 191702.1 & 197832.4 & 185885.6 \\
\hline Fransa & 388.1 & 1002.2 & 2063.9 & 2587.2 & 4321.8 & 5344.8 & 6469.5 \\
\hline Almanya & 106869.0 & 128859.2 & 165998.3 & 164058.5 & 182035.4 & 180181.6 & 192912.3 \\
\hline Macaristan & 8723.7 & 12054.5 & 16026.1 & 13662.1 & 18142.2 & 19000.9 & 4406.2 \\
\hline İzlanda & 19484.5 & 21139.4 & 27711.5 & 13857.0 & 14301.5 & 16578.8 & 17096.0 \\
\hline İrlanda & 91937.3 & 115559.2 & 127487.1 & 88399.3 & 104011.3 & 100883.1 & 93549.0 \\
\hline İsrail & 40935.1 & 47603.5 & 58100.5 & 80593.9 & 94426.3 & 112070.9 & 112462.9 \\
\hline İtalya & 47004.8 & 58729.8 & 73811.8 & 74721.8 & 90050.3 & 94616.6 & 99440.6 \\
\hline Kore & 14834.9 & 27254.7 & 29574.4 & 24290.2 & 32442.3 & 40876.3 & 47821.6 \\
\hline $\begin{array}{l}\text { Lüksembur } \\
\text { g }\end{array}$ & 377.8 & 466.6 & 550.4 & 542.1 & 1215.2 & 1067.3 & 1075.9 \\
\hline Meksika & 77203.0 & 96665.5 & 103622.1 & 90798.8 & 107810.6 & 134749.4 & 132380.8 \\
\hline Hollanda & 730883.1 & 884866.0 & 1137126.6 & 932778.6 & 979400.6 & 1015665.7 & 1055651.9 \\
\hline $\begin{array}{l}\text { Yeni } \\
\text { Zelanda }\end{array}$ & 12376.3 & 12231.7 & 15223.5 & 14771.7 & 14356.1 & 18817.6 & 25961.8 \\
\hline Norveç & 19282.3 & 23440.7 & 29655.2 & 21934.4 & 30309.9 & 33134.8 & 33627.2 \\
\hline Polonya & 26291.7 & 40475.2 & 58048.4 & 47136.7 & 63626.4 & 75238.0 & 67016.5 \\
\hline Portekiz & 22392.7 & 27900.6 & 32910.3 & 28226.4 & 31574.7 & 26356.1 & 17127.4 \\
\hline $\begin{array}{l}\text { Slovak } \\
\text { Cumhuriye } \\
\text { ti }\end{array}$ & 282.9 & 1742.6 & 3365.7 & 4417.2 & 5713.0 & 6523.4 & 7502.6 \\
\hline Slovenya & 428.6 & 646.6 & 923.8 & 990.9 & 1313.0 & 1449.8 & 1549.8 \\
\hline
\end{tabular}




\begin{tabular}{|l|r|r|r|r|r|r|r|}
\hline İspanya & 77409.8 & 97120.9 & 127306.1 & 108733.9 & 122557.8 & 112224.6 & 108246.9 \\
\hline İsveç & 31183.3 & 39093.7 & 41568.9 & 29821.3 & 35954.2 & 47126.5 & 46714.1 \\
\hline İsviçre & 412865.3 & 477970.4 & 537946.4 & 506274.1 & 581203.1 & 661168.3 & 664570.8 \\
\hline Türkiye & 3233.0 & 4024.1 & 8793.7 & 9309.0 & 14543.0 & 16768.5 & 28284.4 \\
\hline $\begin{array}{l}\text { Büyük } \\
\text { Britanya }\end{array}$ & 1670716. & 2135551.6 & 2189057.1 & 1352434. & 1820742. & 2018040.7 & 2232597.8 \\
\hline ABD & 5 & 6 & 3 & & 10839889. \\
& 0 & 10166773. & 10724517. & 8344508. & 9612247. & 10646829. & 10 \\
\hline Ortalama & 446445.6 & 507458.6 & 559799.3 & 441137.9 & 505860.0 & 561740.0 & 588685.3 \\
\hline
\end{tabular}

Kaynak: OECD Data Bank, www.oecd.org/statistics/

Çalışmada bağımlı değişken olarak emeklilik fonu değeri değişkeni alınırken, belirleyicileri olarak da hanehalkı tüketim harcaması, toplam nüfus, kişi başı GSYH, kişi başı sağlık harcamaları, 2008 krizini ifade eden kukla değişken, istihdam oranı, enflasyon, erkeklerin ortalama emeklilik yaşı, kısa dönem faiz oranı değişkenleri dikkate alınmıştır. Emeklilik fon değerine ait olan değişkenin logaritması alınarak yarı logaritmik bir model oluşturulmuştur.

$\mathrm{Bu}$ çalışmada ele alınan 32 OECD ülkesine ait emeklilik fon değeri verileri Tablo 2'de sunulmuştur. Buna göre, 2011 yılında en fazla emeklilik fon değerine sahip olan ülkelerin ABD, İngiltere, Hollanda, Kanada ve Avustralya olduğu görülmektedir. Ayrıca analizlerde kullanılan değişkenlere ait tanımlayıcı istatistikleri Tablo 3'de verilmiştir.

Tablo 3. Tanımlayıcı İstatistikler

\begin{tabular}{|l|r|r|r|r|r|}
\hline \multicolumn{1}{|c|}{ Değişkenler } & Gözlem & Ortalama & Std. Sapma & \multicolumn{1}{c|}{ Min } & \multicolumn{1}{c|}{ Max } \\
\hline Emeklilik fon değeri & 224 & 515875.2 & 1754503 & 282.92 & $1.08 \mathrm{E}+07$ \\
Emeklilik fon değerinin logaritması & 224 & 4.669411 & 0.9821204 & 2.452 & 7.035 \\
Hanehalkı tüketim harcaması & 224 & $6.46 \mathrm{E}+11$ & $1.60 \mathrm{E}+12$ & $7.54 \mathrm{E}+09$ & $9.49 \mathrm{E}+12$ \\
Toplam nüfus & 224 & $3.39 \mathrm{E}+07$ & $5.63 \mathrm{E}+07$ & 296734 & 312000000 \\
Kişi başı GSYH & 224 & 29884.31 & 11452.74 & 11394.04 & 73912.59 \\
Kişi başına sağlı harcamaları & 224 & 3090.175 & 1582.272 & 620.8383 & 8607.876 \\
2008 krizi & 224 & 0.1428571 & 0.3507108 & 0 & 1 \\
İstihdam oranı & 224 & 66.48222 & 7.866033 & 42.2 & 85.15 \\
Enflasyon & 224 & 2.883482 & 2.133261 & -4.5 & 12.7 \\
Erkeklerin ortalama emeklilik yaş1 & 224 & 63.61339 & 3.451262 & 57.3 & 74.1 \\
Kisa dönem faiz oranı & 224 & 3.787321 & 2.989687 & 0.12 & 17.32 \\
\hline
\end{tabular}

\subsection{Bulgular}

$\mathrm{Bu}$ çalışmada, 32 OECD ülkesi (Yunanistan ve Japonya hariç) için bireysel emeklilik fonlarının belirleyicileri panel regresyon model kullanılarak incelenmiştir. Bu amaçla elde edilen sabit etkiler modeli ve FGLS yöntemine ait modeller Tablo 4'de verilmiştir. Tablo 4'de 
görüldüğü gibi Hausman testi, panel veri analizinde kullanılan modellerden sabit etkiler modelinin kabul edilmesi gerektiğini gösterir. Aynı zamanda $\mathrm{F}$ testi, birim etkinin varlığını yani havuzlanmış regresyon modeline göre sabit etkiler modelinin seçilmesi gerektiğini göstermektedir. Ayrıca modelin varsayımları incelendiğinde, Modifiye edilmiş Wald testi ile farklı varyans olduğu sonucuna varılmıştır. Pesaran test, birimler arası korelasyonun olmadığını göstermektedir. Ayrıca Baltagi-Wu LBI testi modelde otokorelasyon olduğunu göstermektedir. $\mathrm{Bu}$ çalışmada elde edilen sabit etkiler modelinde farklı varyans ve otkorelasyon söz konusu olduğu için sabit etkiler modeli yerine bu varsayımlara karşı dirençli tahminciler veren FGLS regresyonu elde edilmiştir. Elde edilen modelin genel olarak anlamlılığını gösteren Wald istatistiği oldukça yüksek ve anlamlıdır.

FGLS modelinden elde edilen bulgulara göre, bireysel emeklilik fonları üzerinde hanehalkı tüketim harcaması, kişi başına GSMH, 2008 krizi, erkeklerin ortalama emeklilik yaşı değişkenlerinin etkisi negatif iken toplam nüfus, sağlık harcamaları, istihdam oranı değişkenlerinin pozitiftir. Bu değişkenlerin katsayıları istatistiki olarak anlamlı ve iktisadi beklentilere uygundur. Enflasyon ve kisa vadeli faizi oranı değişkenlerinin katsayıları için istatistikî olarak anlamlı sonuçlara ulaşılmamıştır. Şener ve Akın (2010)'nun Türkiye için yaptıkları çalışmada bireysel gelir artışlarının emeklilik fonlarına olan talebi arttırdığı sonucu çalışmada ulaşılan sonuçları destekler niteliktedir. Ayrıca Blöndal ve Scarpetta (1998)'in OECD ülkeleri için yaptı̆̆ 1 çalışmada yaş faktörünün bireysel emeklilik üzerinde etkisi olduğu gösterilmektedir. 
Tablo 4. Sabit Etkiler ve Esnek Genelleştirilmiş En Küçük Kareler (FGLS) Tahmin Sonuçları

\begin{tabular}{|c|c|c|c|c|c|c|}
\hline \multirow[b]{2}{*}{ Bağımsız Değișkenler } & \multicolumn{3}{|c|}{ Sabit Etkiler Modeli } & \multicolumn{3}{|c|}{ FGLS } \\
\hline & Katsayı & $\begin{array}{c}z \\
\text { değer } \\
i\end{array}$ & Olasılık & Katsayı & $\begin{array}{c}z \\
\text { değer } \\
\text { i }\end{array}$ & Olasılık \\
\hline Hanehalkı tüketim harcaması & $-2.85 \mathrm{E}-14$ & -1.62 & 0.108 & $-7.85 \mathrm{E}-14$ & -2.53 & $0.012 * *$ \\
\hline Toplam nüfus & $3.27 \mathrm{E}-10$ & 0.65 & 0.516 & 1.13E-09 & 1.85 & $\begin{array}{r}0.064 * * \\
*\end{array}$ \\
\hline Kişi başı GSMH & 0.0000418 & 3.51 & $0.001 *$ & $0.0000247^{-}$ & -4.82 & $0.000^{*}$ \\
\hline Sağlık harcamaları & 0.0002265 & 7.04 & $0.000 *$ & 0.0002238 & 3.65 & $0.000 *$ \\
\hline 2008 krizi & $0.0311665^{-}$ & -0.95 & 0.343 & -0.066855 & -1.7 & $0.090 *$ \\
\hline İstihdam oranı & 0.0159526 & 2.21 & $0.029 * *$ & 0.034195 & 5.1 & $0.000 *$ \\
\hline Enflasyon & 0.0133793 & -1.75 & $\begin{array}{r}0.082 * * \\
*\end{array}$ & 0.0141876 & -1.36 & 0.174 \\
\hline $\begin{array}{l}\text { Erkeklerin ortalama emeklilik } \\
\text { yaşı }\end{array}$ & 0.0018334 & 0.63 & 0.526 & 0.0061994 & -2.19 & $0.028 * *$ \\
\hline Kısa dönem faiz oranı & $0.0181337^{-}$ & -2.61 & $0.010 *$ & 0.005745 & 0.49 & 0.625 \\
\hline Sabit & 1.663336 & 3.91 & $0.000 *$ & 2.864395 & 6.2 & $0.000 *$ \\
\hline Gözlem sayısı & 224 & & & & & \\
\hline Grup sayıs1 & 32 & & & & & \\
\hline Zaman periyodu & 7 & & & & & \\
\hline Wald $\chi 2(8)$ & 93.37 & & $0.000 *$ & & & \\
\hline $\mathrm{F}(31,184)$ test & 260.66 & & $0.000 *$ & & & \\
\hline Hausman test istatistiği & 15.550 & & $0.030 * *$ & & & \\
\hline Farklı varyans testi & & & & & & \\
\hline Modified Wald test- $\chi 2(32)$ & 5091.81 & & $0.000 *$ & & & \\
\hline Otokorelasyon testi & & & & & & \\
\hline Baltagi-Wu LBI & 1.3592 & & & & & \\
\hline Birimler arası korelasyon & & & & & & \\
\hline Pesaran test & 1.329 & & 0.1838 & & & \\
\hline
\end{tabular}

olarak anlamlılığı gösterir.

\section{SONUÇ}

Bireysel emeklilik fonlarının OECD ülkelerinin GSYIH içerisinde ortalama yüzde 77 gibi bir paya sahip olması, hem emeklilik sisteminin nasıl hızlı bir şekilde böyle önemli bir yapıya sahip olduğunu, hem de emeklilik fonlarının genel olarak hangi değişkenlerden etkilendiğini akıllara getirmektedir. Konuyla ilgili olarak yapılan çalışmalar genel olarak emeklilik fonlarının getiri oranları üzerine yapılmış olsa da, Şener \& Akın (2010) ve Blöndal \& Scarpetta (1998)'nın çalışmaları emeklilik sistemine giriş ve sonrasına ilişkin önemli tespitleri bulunan çalışmalardır. 
Yapılan bu çalışmada da emeklilik fonları daha genel bir perspektiften ele alınarak, literatüre ek bir katkı yapılması amaçlanmıştır. Çalışmadan elde edilen sonuçlara göre, hanehalkı tüketim harcaması, kişi başına GSYH, 2008 küresel krizi, erkeklerin ortalama emeklilik yaş1 değişkenlerinin bireysel emeklilik fonları üzerindeki etkisi negatif bulunmuştur. İktisadi beklentiler açısından bakıldığında, özellikle 2008 küresel krizi tüm dünyanın finans piyasasını derinden etkilediği gibi, emeklilik fonlarını da etkilemiştir. Hanehalkı tüketim harcamalarının artması, bireysel tasarrufları azaltmakta ve bu da doğrudan fonları olumsuz etkilemektedir. Kişi başına düşen GSYH'daki artışın emeklilik fonları üzerindeki negatif etkisi ise, bireylerin geleceğe ilişkin endişelerinin olmaması ile açıklanabilir. Erkeklerin ortalama emeklilik yaşındaki artışın negatif etkisi ise, bireylerin daha geç emeklilik ile karşı karşıya kalmalarına neden olacaktır. Bu da bireysel emeklilik sistemine girişi olumsuz etkileyebilmektedir. Toplam nüfus, sağlık harcamaları, istihdam oranı değişkenlerinin etkisi ise pozitif bulunmuştur. Toplam nüfus artışı, ilave istihdam yaratabileceğinden emeklilik fonlarını olumlu etkilemektedir. Sağlık harcamalarındaki artışa bağlı olarak, emeklilik yatırımları da zamanla hız kazanmaktadır. İstihdam oranındaki artışta yine sisteme girişi dolaylı olarak etkilemektedir. 


\section{KAYNAKÇA}

APAK, Sudi ve Kamer Hagop Taşçıyan (2010). "Türkiye'de Bireysel Emeklilik Sisteminin Gelişimi”, Ekonomi Bilimleri Dergisi, Cilt:2, Say1:2, ss. 121-129.

BALTAGI, Badi H. (2008). Econometric Analysis of Panel Data, John Wiley \& Sons., Ltd, U.K.

BAYRAKTUTAN, Yusuf ve Işıl Demirtaş (2011). "Gelişmekte Olan Ülkelerde Cari Açığın Belirleyicileri: Panel Veri Analizi”, Kocaeli Üniversitesi Sosyal Bilimler Enstitüsü Dergisi, Cilt: 22, Sayı:2, ss.1-28.

BIKKER, Jacob, Dirk Broeders, David Hollanders and Eduard Ponds (2009). "Pension Funds' Asset Allocation and Participant Age: A Test of The Life-cycle Model", http://www.dnb.nl/en/binaries/Pension\%20funds\%20asset\%20allocation_ tcm47-224135.pdf (29.02.2014).

BİLGINOĞLU, Mehmet Ali ve Gökçe Maraş (2011). "Avrupa Birliği ve Türkiye'de Mali Saydamlığın Panel Veri Yöntemi ile Analizi”. Ege Akademik Bakış, 11 (Özel Sayı), ss. 59-73.

BLAKE, David (2003). "Financial System Requirements for Successful Pension Reform", http://eprints.lse.ac.uk/24862/1/dp463.pdf (01.03.2014).

BLONDAL, Sveinbjörn and Stefano Scarpetta (1998). "The

Retirement Decision in OECD Countries",
http://www.oecd.org/eco/labour/1866098.pdf (29.02.2014).

CHAN-LAU, Jorge A. (2004). "Pension Funds and Emerging Markets", https://www.imf.org/external/pubs/ft/wp/2004/wp04181.pdf (29.02.2014).

CORDINA, Gordon and Aaron George Grech (1999). "Funded Pension Schemes: Economic Effects and Policy Implications", http://mpra.ub.uni-muenchen.de/33615/ (01.03.2014).

ÇETIN, Murat ve Eyyup Ecevit (2010). "Sağlık Harcamalarının Ekonomik Büyüme Üzerindeki Etkisi OECD Ülkeleri Üzerine Bir Panel Regresyon Analizi”, Doğuş Üniversitesi Dergisi, Cilt:11, Sayı:2, ss.166-182. 
ERKAN, Volkan (1999). "Dış Proje Kredisi Kullanan Kamu Yatırımlarının Gelişimi ve Değerlendirilmesi (1988-1997)”, DPT Uzmanlık Tezi, DPT, Ankara.

GREENE, William H. (2003). Econometric Analysis. McMillan, New York.

GUILLÉN, Jorge (2011). "Latin American Private Pension Funds' Vulnerabilities", http://www.economiamexicana.cide.edu/num_anteriores/XX-2/04_EMJorgeGuillen(357-378).pdf (29.02.2014).

GUJARATI, Damodar N. (2004). Basic Econometrics, McGraw-Hill, New York.

GÜVENEK, Burcu ve Volkan Alptekin (2010). "Enerji Tüketimi ve Büyüme İlişkisi: OECD Ülkelerine İlişkin Bir Panel Veri Analizi”, Enerji, Piyasa ve Düzenleme, Cit:1, Sayı: 2, ss.172-193.

HSIAO, Cheng (1985). "Benefits and Limitations of Panel Data", Econometric Reviews, Vol: 4, No:1, pp. 121-174.

JONHSTON, Jack and John Dinardo (1997). Econometric Methods, McGraw-Hill, New York.

KARABAY, Melisa Erdilek, Özgür Akpınar, Neşe Çoban Çelikdemir, Seher Tezergil ve İskender Demirbilek (2012). Hayat Sigortaları ve Bireysel Emeklilik Sistemi, Editör: Fuat Erdal, I.Bask1, T.C. Anadolu Üniversitesi Yayını No: 2513, Açıköğretim Fakültesi Yayını No: 1484, Eskişehir.

KENNEDY, Paul (2006). Ekonometri Kılavuzu, 5. Baskı, Çev. Muzaffer Sarımeşeli ve Şenay Açıkgöz, Gazi Kitabevi, Ankara.

KORKMAZ, Turhan ve Hasan Uygurtürk (2007). "Türk Emeklilik Fonlarının Performans Ölçümünde Regresyon Analizinin Kullanılması", ZKÜ Sosyal Bilimler Dergisi, Cilt: 3, Say1: 5, ss. 37-52.

LÓPEZ-VILLAVICENCIO, Antonia and Sandra Rigot (2013). "The Determinants of Pension Funds' Allocation to Private Equity", http://ssrn.com/abstract=2363356 (29.02.2014). 
NJUGUNA, Amos Gitau (2011). "Determinants of Pension Governance: A Survey of Pension Plans in Kenya", International Journal of Business and Management, Vol: 6, No: 11, pp. 101-111.

OECD (2013a). "Pension Markets in Focus", http://www.oecd.org/pensions/PensionMarketsInFocus2013.pdf (03.03.2014).

OECD (2013b). "Pensions at a Glance", http://www.oecd.org/pensions/publicpensions/OECDPensionsAtAGlance2013.pdf (03.03.2014).

OKTAYER, Nagihan ve Asuman Oktayer (2007). "Özel Emeklilik Fonlarının Finansal Piyasaların Gelişimine Etkileri”, Afyon Kocatepe IIİBF Dergisi, Cilt: IX, Sayı: II, ss. 55-80.

ÖZEL, Özgür ve Cihan Yalçın (2013). "Yurtiçi Tasarruflar ve Bireysel Emeklilik Sistemi: Türkiye'deki Uygulamaya İlişkin Bir Değerlendirme", Türkiye Cumhuriyet Merkez Bankası, http://www.tcmb.gov.tr/research/discus/2013/WP1304.pdf (03.03.2014).

ÖZER, Mustafa, ve Kemal Biçerli (2003). "Türkiye'de Kadın İşgücünün Panel Veri Analizi”, Anadolu Üniversitesi Sosyal Bilimler Dergisi, Cilt: 3, Say1:1, ss. 55-86.

SELIM, Sibel, KOÇTÜRK, O.Murat ve ERYİĞİT, Pınar (2014). "Türkiye'de Yatırım Teşvikleri ve Sabit Yatırımların İstihdam Üzerine Etkisi: Panel Veri Analizi”, Ege Akademik Bakış, Cilt:14, Sayı:4: 661673.

ŞENER, Orhan ve Faruk Akın (2010). "Özel Emeklilik Fonları ve Türkiye'de Bireylerin Bireysel Emeklilik Sistemine Giriş Kararlarını Etkileyen Faktörlerin Belirlenmesi Üzerine Bir Araştırma". Marmara Üniversitesi İIBBF Dergisi, Cilt: XXVIII, Sayı: 1, ss. 291-312.

TATOĞLU, Ferda Yerdelen (2012). Panel Veri Ekonometrisi, Beta Basım A. Ş, İstanbul.

UYAR, Hilal İlgin (2012). "Bireysel Emeklilik Sistemi İle Ekonomik Göstergeler Arasındaki İlişkinin İncelenmesi”, Mali Çözüm Dergisi, Say1 110, ss. 71-96. 
YILMAZ, Binhan Elif ve Sevinç Yaraşır (2009). "Türkiye'de ve OECD Ülkelerinde Tasarruf- Yatırım Açıkları ve Dış Kaynak İhtiyacı”, Marmara Üniversitesi İïF Dergisi, Cilt: XXVII, Sayı: 97-128. 